\title{
Why Do People Flee? Revisiting Forced Migration in Post-Saddam Baghdad
}

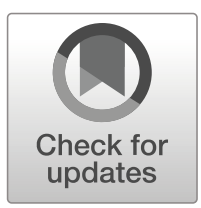

\author{
Duygu Ozaltin $^{1}$ (D) $\cdot$ Farah Shakir $^{2} \cdot$ Neophytos Loizides $^{1}$
}

Published online: 2 April 2019

(C) The Author(s) 2019

\begin{abstract}
When faced with political violence, why do some people choose to leave their homes while others stay? This article looks for motivations, particularly socioeconomic factors, behind decisions to stay or go. Drawing on new survey data from postSaddam Baghdad, it confirms the general axiom that violent conflicts cause people to flee. However, the results are inconclusive in terms of the effect of socioeconomic circumstances as a major push or pull factor. Patriotism does not have an impact on migration intentions, and optimism about Iraq's future does not suffice as a pull factor. Interestingly, people who intend to flee Iraq are better educated, contrary to the general far right media portrayal of refugees.
\end{abstract}

Keywords Refugees · Forced migration intentions · Internally displaced · Forced displacement

\section{Introduction}

Despite significant efforts to analyse the factors behind forced migration (Schmeidl 1997; Davenport et al. 2003; Adhikari 2012), few studies have attempted to explain the intentions to escape conflict zones. Concentrating on what happens after people flee from their countries not only introduces selection bias but also leaves a "black hole" in the forced migration puzzle by skipping the phase where decision-making happens. As Robinson and Segrott (2002: 7) state, "the decision to flee ... arise(s) from an individual's past, represent(s) that individual's present and frequently shape(s) their future". Without knowing the factors that produce forced displacement, solutions to

Duygu Ozaltin

do261@kent.ac.uk

1 School of Politics and International Relations, University of Kent, Canterbury, UK

2 United Learning, Peterborough, Cambridgeshire, UK 
prevent it are bound to be a quick and insufficient fix of an on-going issue of critical importance for human rights and world politics in general.

Admittedly, intentions do not always lead to migration, as dynamic conditions may impact intentions (De Jong et al. 1985; De Jong 2000), and there is a risk of over-reporting (Etling et al. 2018), with many studies seek to match intention to action. For example, van Dalen and Henkens (2008) track respondents to an immigration survey in the Netherlands and observe migration intention translating into behaviour; Bertoli and Ruyssen (2018) find a significant association between the annual number of intended migrants (provided by Gallup World Polls) and the actual migration flows to OECD destinations; Tjaden et al. (2019) show a strong association between intentions and flows based on data of 160 countries. Our goal is to explore the drivers of those intentions but not to debate their robustness in forecasting actual migration behaviour.

Carling and Schewel (2018) recently described migration intentions as the intermediary step in the transformation of aspirations into action, but they argue "migration is the combined result of two factors: the aspiration and the ability to migrate". The definition is insufficient in the under-studied context of forced migration because it implies that if someone does not have the ability to migrate, aspiration stops short of genuine intention and remains a dream. The ability to migrate is not a pre-condition of actual forced migration. Consider, for example, the thousands of asylum seekers continuing to drown in the Mediterranean, not because they miscalculate their ability to cross the sea, but because they are willing to risk their lives to do so.

Based on the definition that forced displacement is "a migratory movement in which an element of coercion exists, including threats to life and livelihood" (IOM 2011), we propose the impact of the coercion experienced by an individual in a conflict environment plays a role in that person's formation of an intention to stay or leave regardless of his or her ability to migrate. A causal relationship of this nature would explain why some people choose to remain, while others leave, although both have the ability to do so.

The process whereby intentions form may be relatively monotone in voluntary migration when the aspiration to migrate is economic, but socioeconomic factors are not as easily distinguishable in conflict settings. They may affect people who want to migrate because they have the skills, resources and connections and people who feel insecure and want to avoid conflict. Thus, despite general agreement that migration intentions are likely to form in places of conflict, there is no consensus on the range and impact of additional factors. With this in mind, instead of looking at people who have already migrated, we probe the dynamics of remaining and leaving intentions; by doing so, we avoid selection bias. By focusing on migration intentions, we also prevent the bias induced by relying on host-country data; immigration policies make such reliance problematic (Liebig and Sousa-Poza 2004; van Dalen and Henkens 2008). Finally, understanding migration intentions can have significant policy implications; policies to manage, limit or prevent migration flows within or beyond the borders of a state can be more effective if factors turning aspiration into behaviour are identified before actual migration occurs.

In a conflict environment, it is realistic to expect it will take a relatively longer time to bridge aspiration and migration; potential migrants face numerous obstacles, including obtaining the funds to travel, gaining access to an escape route, gathering 
information about migration procedures and considering the possible rupture of family bonds. It is therefore typical for studies measuring intentions and behaviour to have a time lag of a number of years (De Jong et al. 1985; van Dalen and Henkens 2013), particularly in developing countries, such as Iraq, where preparation to leave may take significantly longer. ${ }^{1}$ Although outcomes-based measures provide a more accurate estimation of migration levels, a methodology relying on migration outcome measures will always have a time lag (Stats NZ 2017), and the importance of time cannot be underestimated when civilian lives are in danger.

This article uses a 2015 survey conducted in the Baghdad region to analyse the reasons underlying intentions to stay or migrate internally (displaced persons) or externally (refugees) in the context of armed conflict and builds a new theoretical model based on connections of various (social capital and socioeconomic) determinants.

\section{Literature and Theory}

There are multiple reasons for the slow development of forced migration literature, including the unavailability of data and the lack of broader theoretical tools across disciplines. Even though the phenomenon may be too complex to explain with one major theory (Vezzoli et al. 2017), push and pull factors (Ravenstein 1885, 1889; Lee 1966) are common points of reference in the literature (Etling et al. 2018). In a nutshell, push factors, such as poverty, political instability and religious intolerance, induce people to move out of their current location, whilst pull factors, such as democratic governance, economic prosperity and job opportunities, attract them to a new one.

Violence (Weiner 1996; Moore and Shellman 2006, 2007; Steele 2009), economic circumstances (Schmeidl 1997; Neumayer 2005; Van Hear 2006) and cultural networks (Schmeidl 1997; Davenport et al. 2003; Wood 2008; Edwards 2009) are generally accepted as the main push/pull factors of forced migration. Although we might expect armed conflicts, political violence or persecution to be the number one push factor, not everyone leaves (Zolberg et al. 1992; Schmeidl 1997; Davenport et al. 2003; Moore and Shellman 2004; Melander and Öberg 2006), and this particularly interests us. As we see it, a closer look at the social capital and socioeconomic circumstances may explain why some choose to leave an area of conflict while others stay.

By focusing on what pushes or pulls people during violent conflicts, this article explores the effect of socioeconomic and social capital factors in the decision to move. Social capital consists of informal or institutionalized networks linking people, often based on a shared sense of common identity (Stefanovic et al. 2014), thus making it an important push/pull factor, depending on the location of the networks. Socioeconomic factors include economic status based on work experience, occupation, income level

\footnotetext{
${ }^{1}$ The survey's questions are based on a time lag of three years to accommodate the challenging preparation time. They include the following: "In your opinion, how likely it is that the armed conflict will stop within the next 3 years?"; "How likely it is for you to migrate within Iraq in the next 3 years"; "How likely it is for you to migrate outside Iraq in the next 3 years?" A three-year horizon is usually the timeframe required to bridge aspiration to intention in most developing post-conflict countries for someone to start preparations and official applications for an immigration process.
} 
and education (Borjas 1990; Ibanez and Velez 2008; Ruiz and Vargas-Silva 2013). Real or potential changes in socioeconomic status are an obvious push factor, but they can also act as a pull factor, with individuals deciding to move based on where they are likely to have better opportunities.

By focusing on the socioeconomic factors, our purpose is to test the popular claims of migration policies that providing financial aid to migration generating countries and increasing their socioeconomic well-being would prevent further flows. Previous studies analysing the relationship between socioeconomic factors and forced displacement have multiple limitations. For one thing, they concentrate on refugees already in exile (Betts 2016; McAuliffe and Jayasuriya 2016) and ignore potential refugees or internally displaced persons (IDPs). For another, they focus on the consequences of displacement (Jacobsen 2005; Cortes 2004; Collier 2013) not on the initial process of decision-making. ${ }^{2}$ They also overlook those who stay behind, missing an opportunity to compare forced migrants with non-migrants. Finally, a concentration on refugees inevitably leads to a strict categorization of forced migration movements, and those outside existing categories tend to disappear (Martin et al. 2014). Only a handful of studies have given this question the meticulous attention it requires. Baser (2014) discusses how forced migration does not automatically generate diasporas, and the multi-generational, cross-country study of migrants and nonmigrant family members by Guveli et al. (2017) is one of very few in the voluntary migration literature.

Meanwhile, the social capital literature has limited engagement with forced displacement, concentrating on the integration of refugees (Loizos 2000; Morrice 2007), asylum seekers and return migration (Stefanovic and Loizides 2011; Stefanovic et al. 2014; Smith 2013). Case studies (Calhoun 2010; BohraMishra and Massey 2011; Randell 2016) are limited because of a lack of data and/or difficulty obtaining data in the conflict-prone zones that typically produce forced displacement.

Overall, more effort is dedicated to the relationship between the presence of refugees and conflict than to the root causes of forced displacement. For example, Loescher and Milner (2005) say that continuous refugee movements are a source of on-going conflict and instability, complicating peace processes and weakening socioeconomic development. Neumayer's (2005) "bogus refugees" thesis supports the popular perception of asylum seekers as mainly economically driven; economic circumstances in the origin country are argued to be important predictors of the volume of asylum seekers coming to Western Europe. Zimmerman (2011) questions the generally accepted narrow definitions of refugees and notes the resulting conclusions about refugees as either genuine or "bogus". Finally, some studies (Schmeidl 1997; Moore and Shellman 2007) show countries with higher levels of economic development generate fewer refugees, even during conflicts, whilst Tsourapas (forthcoming) argues refugees "become a source of revenue" for "refugee rentier" host states.

\footnotetext{
${ }^{2}$ A refugee is "a person who, owing to well-founded fear of being persecuted for reasons of race, religion, nationality, membership of a particular social group or political opinion, is outside the country of his nationality and is unable or, owing to such fear is unwilling to avail himself of the protection of that country" according to the 1951 Convention and 1967 Protocol (Protecting Refugees). Internally displaced people are "displaced in their own country as a result of conflict or human rights violations" (UNHCR 2010).
} 
The availability of modern research techniques has greatly aided researchers - but it has not led to consensus. Several large-n analyses find a relationship between forced migration and the level of economic development and poverty in the origin and destination (Adhikari 2012; Moore and Shellman 2007), and Zetter et al. (2013) say the underlying factors of conflict-induced migration are often a combination of political and economic factors. However, others do not find a significant connection between GNP and GDP per capita and forced displacement (Davenport et al. 2003; Melander and Öberg 2007; Khawaja et al. 2010).

Considering these contradictory results, it seems wise to look more closely at how social capital and socioeconomic variables contribute to the migration decision, particularly considering the academic and policy worlds tend to overvalue the latter. In fact, it is not uncommon for states to mix the meaning of asylum seekers and economic migrants (Cenciarelli et al. 2017) with the assumption that economic factors are dominant to avoid their legal obligations under the 1951 Refugee Convention (UNHCR n.d.). Such actions lead to "more labels and fewer refugees" as Zetter (2007) puts it, and the stigmatization of refugees in political rhetoric and media (Goodman et al. 2017) counters scientific evidence that economic variables are not the most significant drivers of the intention to migrate. Recent work by Duda-Mikulin (2018) shows that as migrants are becoming more mobile, their various motivations to migrate are increasingly inseparable and require an approach that captures the dynamism of decision making by considering the "intersection" of motivations. We agree. Consequently, we adopt this approach.

\section{Main Hypotheses on Individual Decision-Making and Socioeconomic Factors}

The initial stage of forced migration begins with an individual (micro-level) decision to leave or stay, and "the decision-making of individual actors is embedded in social contexts" (Haug 2008: 590). The literature typically relies on benefit-cost models to analyse the factors driving micro-level decision making. Benefit-cost models are associated with economic considerations and assume potential migrants rationally estimate the costs and benefits of moving to alternative locations and migrate to where the expected discounted net returns are greatest over some time horizon (Borjas 1990). In the case of forced migration, they are commonly associated with economic opportunities for refugees whose resource base has been destroyed by conflict. They also analyse how displaced people affect the economies of the country to which they move (Zetter 2012a, 2012b; Weinstein 2002; Damelang and Haas 2012; Ruiz and Vargas-Silva 2013). At this point, however, little research has focused on the former.

To address this gap, we use data from Iraq to analyse how socioeconomic standing in the place of origin effects the decision to move (or not). We include both potential refugees and potential internally displaced people with no previous history of displacement based on the rationale that they are representative of the global population of potential migrants. Unlike the majority of similar studies, ours asks why people decide to stay under seemingly dire circumstances. In particular, we test the following hypotheses. 
Previous findings point to a relationship between violence and forced displacement, but we are curious about why some people choose to stay in their homes despite experiences of direct or indirect violence. To answer this question, we take the following steps: first, we explore demographic predictors; next, we add political violence-related variables; finally, we include social capital.

We build our first model to explore the effect of age, civil status, employment, income, ethnicity and education. Although we would expect the decision to migrate to be evenly distributed between males and females in line with historical trends of forced migration (UNHCR 2016: 54), we exclude gender, as the ratio of females to males in our data is very low (8\%). As older people have specific challenges and risks, we expect the odds of migration to decrease with age.

Unlike voluntary migration, in forced migration, we hypothesize close family ties increase the odds of migration because of concerns about the security of family members. Whilst married people are less likely to migrate because of the higher costs of relocating the whole family, according to the voluntary migration literature (Mincer 1978; Cooke 2008; Mueller 1982), this may not be the case for forced migration, as the cost of leaving part of the family behind may be higher than moving together; they may have to face a life-threatening situation and/or not be able to unite for an extended period. Given these considerations, we hypothesize a positive relationship between the decision to flee and having a family.

The next hypothesis focuses on income level. We assume that low income in the area of origin can act as a push factor, whilst higher levels of income can cause people to remain, even with the threat or memory of violence. Specifically, higher income implies better economic opportunities (Adhikari 2012) and, as such, is likely to play a major role in micro-level decision making. We also hypothesize economic stability is a major pull factor and test this theory by looking at the types of jobs people hold. Arguably, those with permanent jobs will be less likely to move; if their career perspectives are considerably below their education level, however, they may seek an alternative location to build wealth and a better future. Given the specific context of Iraq, we hypothesize Sunni identity increases the odds of migration, as the sectarian divide between Sunnis and Shi'ite has put pressure on the previously dominant (under Saddam Hussein's regime) Sunni minority.

Finally, we hypothesize an association between level of education and the intention to migrate. The literature concentrates on the education level of refugees and potential issues in the destination country (Hartog and Zorlu 2009; Dryden-Peterson 2011; Spreen and Vally 2012), with less effort to understand the relationship between the level of education in a country with on-going armed conflict and the intention to migrate. Researchers commonly assume potential refugees and potential IDPs are generally not well-educated, thereby suggesting better education opportunities in the area of origin may prevent a high volume of migration. However, we hypothesize that higher levels of educational qualifications during political unrest will push people away, in manner much like voluntary economic migration.

In the second model, we examine the effects of political violence, through three hypotheses. First, positive expectations about the end of the conflict will decrease the odds of migration. Specifically, we hypothesize respondents who think the conflict is likely to stop within the next three years are less likely to migrate than those who think it will continue. Second, confidence in the power of negotiations to resolve the conflict 
will decrease the odds of migration. Third, respondents who blame the Shi'ite militia for the violence are more likely to migrate, as the Shi'ite militia is a major fear-inducing factor provoking Sunni-Shi'ite strife and displacement. ${ }^{3}$

In the third model, we analyse the impact of social capital on migration decision making via four hypotheses. The first concentrates on community feeling based on the argument that people who like to live in ethnically mixed communities are less likely to migrate, as they are relatively tolerant of ethnic differences in the living environment and enjoy being part of a diverse culture. The second hypothesis adds religious tolerance to the model; even in the absence of trust, the odds of migration decrease if people are tolerant about living with other groups, including religious sects. However, if they have negative feelings about displaced people in general, they are not likely to become migrants themselves - our third hypothesis. In the fourth, we test the potential effect of patriotism on the decision to migrate; specifically, we hypothesize that Iraqis who think it is their duty to keep their country united are less likely to migrate than Iraqis who do not have a similar attachment to their homeland.

\section{The Iraqi Conflict: History of Forced Displacement}

From the formation of the modern Iraqi state in 1921 up to the overthrow of Saddam's regime in 2003, Iraqi society has seen several waves of forced external and internal displacement. In what follows, we sum them up and give a brief explanation of the reasons for displacement in each instance.

Different Iraqi governments used forced external and internal migration for political reasons throughout the Monarchy (1921-1958); so, forced migration did not develop on the individual level. For example, Sayyid Talib al-Naqib was exiled in 1921 and Jaffer Abu Timn in 1922 (Batatu 2003: 332). Some Shi'a clerics, including al-Khalisi and his sons, were deported to Iran in 1930 (Wardi 1976: 227, 230). In 1931, Shaikh Mahmud, a Kurdish tribal leader seeking an independent Kurdish state, was sent into internal exile to al-Nasiriyya governorate in the south of Iraq after revolting many times against the British and the Iraqi governments between 1919 and 1930 (Tripp 2007: 66). Meanwhile, religious and linguistic affiliations drove Assyrians and Yazidi to migrate to Syria during the 1930s and after the armed conflict with the Iraqi government. By the same token, Kurdish leader Mustafa Brazani, with 3000 of his fighters, was forced to flee Iraq after his revolution against the Iraqi government in 1943 and then exiled to Soviet Union in 1946 (Stansfield 2007: 87).

Although this tool was effective, the rise of the Iraqi army became decisive in controlling opposition and consolidating political control during the 1960s. With the move towards the authoritarian state during the 1960s and the totalitarian state after 1980, forced displacement was to ensure political and economic control. Some Shi'a families, at the beginning of the Iran-Iraq war, many of whom had Iranian roots, were deported to Iran. The total number of these families may have reached

\footnotetext{
${ }^{3}$ Although respondents blame terrorist groups (Al-Qaeda and Isis) the most (94\%) for post-2003 violence in Iraq, when we tested this response on the odds of migration, it was not statistically significant. Although fewer respondents blamed Shi'ite militia (56\%), this was a strong and significant predictor of the odds of migration both within and outside Iraq.
} 
200,000 (Marr 2004: 198). Nearly 100,000 people remained displaced in Basra and other cities from the time of the Iran-Iraq war and following the Second Gulf War (Fawcett and Cohen 2002). The uprising in the southern governorates after 1991, triggered by the regime's repressive approach, economic hardship and the defeat of the army in the war, forced many Shi'a to migrate illegally to Iran and Saudi Arabia. Refha Camp, on the border with Saudi Arabia, included about 200,000 people in 1991; it was closed in 2002 after arranging settlement in a few European countries. Saddam used more than military force to control the Shi'a in the south; he also drained the marshes, damaging the natural environment of the area and the lifestyle of its people, forcing them to migrate to other parts of Iraq.

Kurds were similarly targeted by the regime. The destruction of about 4000 villages between 1988 and 1990 resulted in the displacement or resettlement of up to 1.5 million people (Fawcett and Tanner 2002: 9; Marr 2004: 202). Some settled in other parts of northern governorates and around the major cities, seeking a source of income after the destruction of their agricultural lands. It was also easier for the government to control them there. Others crossed the borders to Iran and Turkey, before moving on to Europe. According to Marr, there were 60,000 to 150,000 refugees in Turkey and about 200,000 in Iran (Marr 2004: 202). After 1991, more Kurds fleeing the brutality of the regime sought refuge in these two states.

In general, there is not strong evidence of socioeconomic factors generating a desire for migration among Iraqis in the period 1921-1958, partly because the social and economic class structures of Iraqi society were not well-developed. However, the tribal leaders who owned the land and wealth in their areas used their authority to control the peasants, keeping them in dire living conditions and leading to a type of economic migration from the countryside to the cities, mainly Baghdad. This resulted in the formation of poor neighbourhoods in the suburbs of Baghdad, known today as al-Shialeh and al-Sader. According to Dawisha, the migrants and long-term urban dwellers clashed, heightening the country's socioeconomic gulf (Dawisha 2013:119). Social policies introduced in 1964 included the nationalisation of banks, insurance companies and industries. The socioeconomic situation deteriorated (Dawisha 2013: 187-188), driving well-known rich families from various ethnic and religious Iraqi groups to migrate to Syria, Lebanon, Europe and the United States. In general, the authoritarian nature of the Iraqi governments during the 1960s and 1970s was the main migratory push factor. The fear of political repression, limitations on freedoms, the role of the army and the desire to protect their wealth drove many rich Iraqis to migrate during this period.

The nationalisation of the oil in 1972 boosted the Iraqi economy and tightened government control of the masses. The 1974 conflict with Kurds and the desire to control Kurdish areas near Kirkuk, where the oil fields were found, prompted the Iraqi government to undertake an Arabization program, mainly in Kirkuk. The program resulted in the deportation of about 45,000 Faili (Shi'a) Kurds to Iran; by 1978, about 1400 villages along the borders of Iran and Turkey had been razed and 60,000 villagers displaced (Marr 2004: 155-158). This policy encouraged Arabic peoples to move to Kirkuk to balance the number of Kurds and Turkmen. At the same time, however, the economic boom attracted different groups of Arab labour during the 1970s and 1980s to work in the oil industry and in other sectors as well (Chatelard 2010: 6). 
The invasion of Kuwait and the economic embargo from 1990 to 2003 contributed to the growth of international migration. Many educated young people, despite the costs and risks of migration, left to seek safety and better life opportunities. The brutality of the Saddam regime and economic hardship were the main push factors at this stage. The Second Gulf War also resulted in the return migration of about two million Arab labourers to Egypt and Sudan (Sirkeci 2005: 198).

In short, displacement, both external and internal, was a feature of Iraqi society throughout the twentieth century. The country's political dynamics were the main push factor driving Iraqis from their homes. Forced migration was a tool employed in the early stages of the formation of the state; it later became systemic, a technique used to maintain political control, as with Kurds and Shi'a, and economic control, as with Arabization. At the same time, the brutal nature of the various Iraqi political systems made the promise of security elsewhere a pull factor for Iraqis fleeing their homes, although the peaceful coexistence of Iraqi groups often prevented large-scale displacement. Over time, links were built between home and the diaspora; in the post-2006 period, this became a decisive pull factor.

Iraq has also seen massive displacements since the American invasion. Despite prohibitive conditions, more than half a million Iraqis repatriated in the period 20032011 (UNHCR 2012: 17). New displacements occurred in 2017: over half a million people became newly displaced within the country, although internally displaced migrants decreased overall by about one million during the same year (UNHCR 2017: 34). By the end of 2017, the total number of the internally displaced exceeded 2.6 million (IDMC 2018).

To sum up, in addition to producing large volumes of refugees and internally displaced people (1.8 million IDPs in 2018) (DTM 2018), Iraq is a useful case to test our hypotheses because of its diverse ethnicity, religion and urban/rural status and its context of renewed/ongoing conflict. The Baghdad region is one of the rare places to both produce and attract forced migrants, in addition to being a zone of protracted conflict fed by ethnic cleavages. ${ }^{4}$ A Baghdad-region survey conducted in 2015 with the support of a British Academy grant, whilst not providing detailed information on every aspect of migration, gave us enough data to draw comprehensive socioeconomic profiles of the respondents, shedding light on the forced migration decision-making process.

\section{Survey Data and Methods}

Data collection took place within the context of an international research project focusing on displacement, federalism and reconciliation in Iraq funded by the British Academy as part of a Mid-Career Research Fellowship awarded to the third author. The survey was carried out by a local Iraqi NGO, the Institute of Youth Development, directed by Dr. Essam Assad, Lecturer in the College of Political Sciences at the University of Al-Nahrain. Although the limitations of conducting surveys in Iraq meant obtaining a nation-wide representative sample was difficult, the survey organisation

\footnotetext{
${ }^{4}$ UNHCR (2016) defines protracted displacements as those with 25,000 or more refugees of the same nationality in exile in a particular country for five consecutive years.
} 
used available government statistics to cover participants across gender and age (all adults 18 and above).

The data used in our article were collected in a survey conducted in Baghdad from May to August 2015. Baghdad was chosen because it receives displaced and internal migrants from different ethnic, religious and sectarian Iraqi groups. It was also the arena for sectarian violence between 2006 and 2008, and we assumed that this would have a huge impact on people's political and social opinions. Survey participants included 513 forcibly displaced internal migrants and 441 people who witnessed cases of displacement but were not displaced themselves.

The first sample included 263 people displaced after the events in Mosul in 2014 (59.5\% Sunni, 39.5\% Shi'a, 1\% Christian) and 250 persons forced to migrate after 2006 because of sectarian violence (even numbers of Shi'a and Sunni). The first sample was tested using both purposive and accidental approaches; participants were from two areas in Karkh District (Western side of Baghdad), which included two of the main Sunni camps, and from two areas in Rusafa District (Eastern side of Baghdad), which included camps for Shi'a and Christian people. The second sample was distributed across 19 areas in Baghdad: 10 in Karkh and 9 in Rusafa.

The data collection procedure ensured participants' informed consent. The interviews were conducted in Arabic. After the data collection, the results were entered anonymously into an SPSS file, and original copies of the questionnaires were destroyed. The interviews comprised face-to-face meetings at the homes of participants. For the purposive approach, as Iraqi tradition and customs put the responsibility of decision-making in the hands of the head of the family, the survey was conducted with that person, whether male or female, as well as the son or the daughter whose age was closest to the person conducting the interview. For the accidental approach, respondents were selected from random roads within various neighbourhoods. The PI took advice from local experts, including the second author, who provided expert advice.

\section{Findings}

We looked at odds ratios of the intention to migrate of both potential refugees and potential internally displaced people based on three models with socioeconomic, political violence and social capital related binary predictors and the intention to migrate as the binary dependent variable. We uploaded the data to Stata to obtain the odds ratios and the pseudo $R^{2}$ (McFadden's) and measured goodness of fit of each model using Stata's classification tables (Fig. 1 and Table 1).

\section{Odds of Migration Outside Iraq (Potential Refugees)}

\section{Socioeconomic Factors}

The first model explores the relationship between intention to migrate outside Iraq and several socioeconomic variables, including employment type, ethnicity and education level. About half of the respondents with the intention to leave are married; all have 


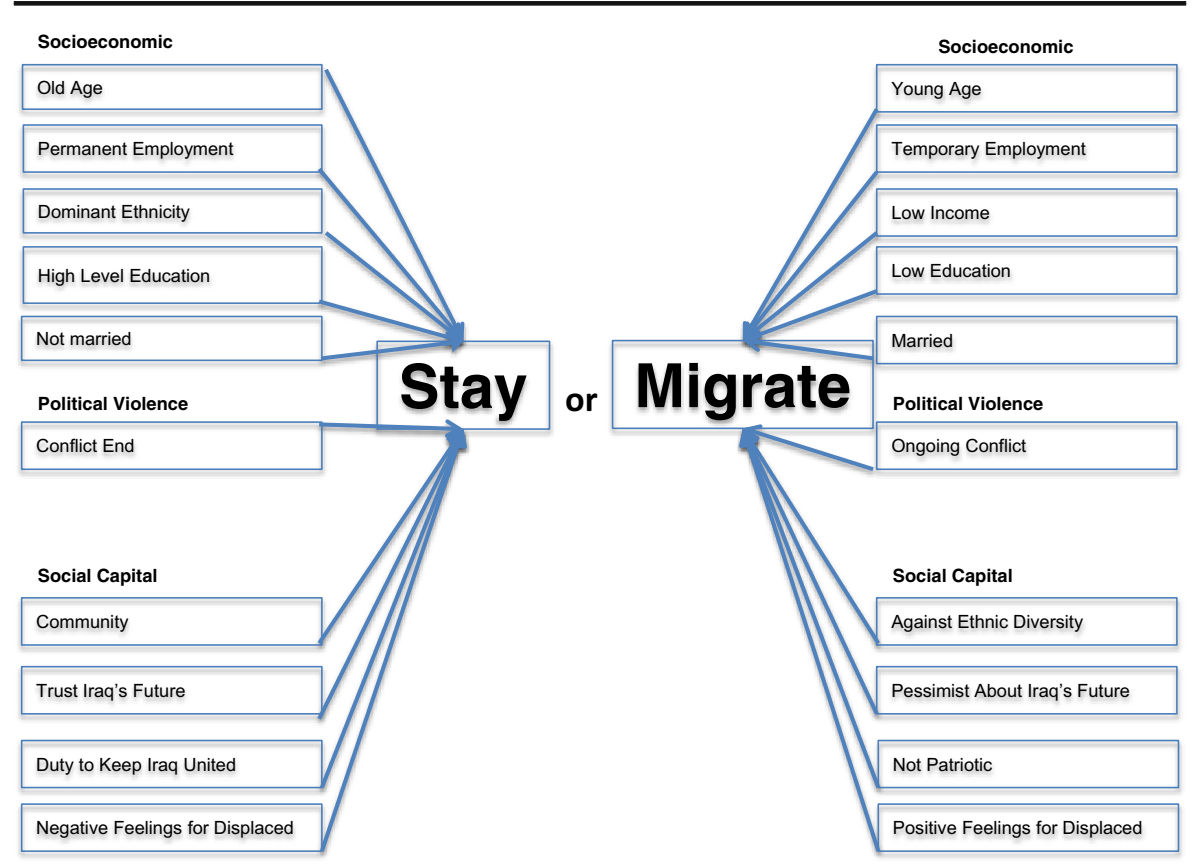

Fig. 1 Decision-making phase of forced displacement

children, and the annual earnings of 58\% are below Iraq's gross national income per capita (World Bank 2015). This profile suggests economic circumstances and worries about the future of younger generations play a role in the intention to move. ${ }^{5}$

However, our hypothesis is not supported when we look at the first model on the effect of socioeconomic factors on the odds of migration (Table 2). Contrary to our expectations, being Sunni, married, permanently employed and having below national average income are not statistically significant. Although age is statistically significant, considering that the average age of all respondents is 34 and the majority (85\%) are younger than 45 , we do not consider this result particularly indicative.

The most important finding related to the demographic profile of potential refugees is the positive relationship between education and the intention to migrate; welleducated Iraqis (with secondary school diplomas or above) are almost three times more likely to leave the country, holding other factors constant. Sixty-three percent of those who intend to migrate outside Iraq are well-educated (51\% of the 441 respondents are well-educated). In comparison, Cheung and Phillimore (2013: 16) find only 37\% of refugees who have fled to the UK have a secondary school diploma or above, whilst three quarters of Syrian refugees in Lebanon have primary education or below (ILO 2013: 19).

\footnotetext{
5 The World Bank includes Iraq in upper-middle income countries with its 2015 GNI per capita as \$5960. Values calculated based on 1 USD $=1095.97$ IQD in 31/12/2015. Below 6 million IQD was categorised as low income (World Bank 2015).
} 


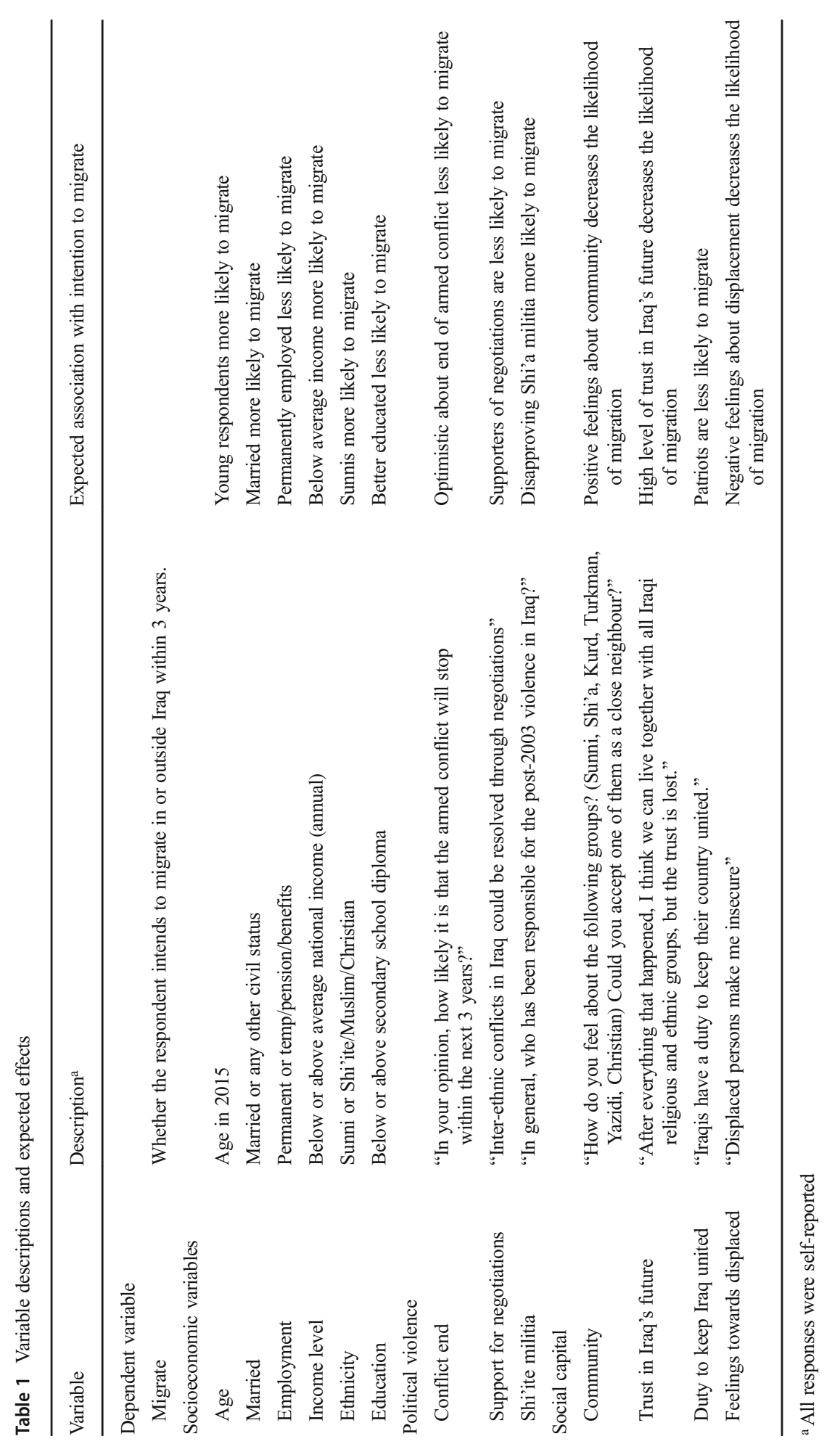


Pseudo $R$-square indicates a weak model fit. Overall, this model classifies $71 \%$ of the cases correctly.

Table 2 Odds ratios for logistic regression of forced migration from Iraq

\begin{tabular}{|c|c|c|c|}
\hline Independent variables & Model 1 & Model 2 & Model 3 \\
\hline \multicolumn{4}{|l|}{ Socioeconomic } \\
\hline Age & $\begin{array}{l}0.928 * * * \\
(0.014)\end{array}$ & $\begin{array}{l}0.915 * * * \\
(0.014)\end{array}$ & $\begin{array}{l}0.918^{* * *} \\
(0.015)\end{array}$ \\
\hline Married & $\begin{array}{l}1.143 \\
(0.267)\end{array}$ & $\begin{array}{l}0.861 \\
(0.215)\end{array}$ & $\begin{array}{l}0.889 \\
(0.227)\end{array}$ \\
\hline Employed & $\begin{array}{l}0.687 \\
(0.183)\end{array}$ & $\begin{array}{l}0.588^{*} \\
(0.166)\end{array}$ & $\begin{array}{l}0.602 * \\
(0.173)\end{array}$ \\
\hline Income & $\begin{array}{l}1.205 \\
(0.260)\end{array}$ & $\begin{array}{l}1.481 * \\
(0.340)\end{array}$ & $\begin{array}{l}1.488^{*} \\
(0.344)\end{array}$ \\
\hline Sunni & $\begin{array}{l}1.461 \\
(0.464)\end{array}$ & $\begin{array}{l}1.343 \\
(0.450)\end{array}$ & $\begin{array}{l}1.298 \\
(0.441)\end{array}$ \\
\hline Education & $\begin{array}{l}2.884 * * * \\
(0.656)\end{array}$ & $\begin{array}{l}2.916 \text { *** } \\
(0.691)\end{array}$ & $\begin{array}{l}2.892 \text { *** } \\
(0.698)\end{array}$ \\
\hline \multicolumn{4}{|l|}{ Political violence } \\
\hline Conflict end & & $\begin{array}{l}2.932 * * * \\
(0.668)\end{array}$ & $\begin{array}{l}2.765^{* * * *} \\
(0.641)\end{array}$ \\
\hline Negotiation & & $\begin{array}{l}0.591 * * \\
(0.141)\end{array}$ & $\begin{array}{l}0.616^{*} \\
(0.156)\end{array}$ \\
\hline Shi' 'ite militia & & $\begin{array}{l}1.958 \text { *** } \\
(0.456)\end{array}$ & $\begin{array}{l}2.050 \text { *** } \\
(0.486)\end{array}$ \\
\hline \multicolumn{4}{|l|}{ Social capital } \\
\hline Community & & & $\begin{array}{l}1.046 \\
(0.083)\end{array}$ \\
\hline Trust in Iraq's future & & & $\begin{array}{l}1.323 \\
(0.322)\end{array}$ \\
\hline United & & & $\begin{array}{l}1.071 \\
(0.341)\end{array}$ \\
\hline Displacement & & & $\begin{array}{l}0.579 * * \\
(0.136)\end{array}$ \\
\hline Constant & $\begin{array}{l}3.901^{* * * *} \\
(1.843)\end{array}$ & $\begin{array}{l}3.272 * * \\
(1.734)\end{array}$ & $\begin{array}{l}2.326 \\
(1.665)\end{array}$ \\
\hline McFadden's $R^{2}$ & $10.4 \%$ & $16.8 \%$ & $17.8 \%$ \\
\hline Number of respondents & 441 & 441 & 441 \\
\hline
\end{tabular}




\section{Political Violence and Forced Displacement}

Exploring the bi-variate effect of directly experiencing or witnessing violence confirms the general axiom that "violence causes people to leave", as there is a statistically significant relationship between various types of violence and the intention to move within or beyond the borders of Iraq in three years. However, only $42 \%$ of respondents with personal experience of violence (verbal abuse, physical injury, imprisonment, torture) intend to migrate within three years, indicating that on-going conflict pushes people away, but it is not the sole factor. Nearly half of all respondents with a history of personal or indirect violence favour migrating outside Iraq, even though they think the conflict is likely to stop within the next three years. What pushes these likely migrants away if they expect to find themselves in a conflict-free environment in the near future? We clearly need to look beyond political and conflict indicators.

The second model in Table 2 adds three variables related to political violence and includes socioeconomic variables, namely, the beliefs that the conflict is likely to end in three years, negotiations can resolve inter-ethnic conflicts and the Shi'ite militia is to blame for post-2003 violence in Iraq. While the statistical significance of age, being married, Sunni and well-educated remains unchanged, having permanent employment and low income are significant. Holding other variables constant, the permanently employed are about six times more likely to stay than to migrate, whilst respondents with below national average income are 1.5 times more likely to migrate, thus supporting our hypotheses on employment and income. All of the political violence related items are strong predictors; respondents who hold the Shi'ite militia responsible for post-2003 violence are two times more likely to migrate than those who do not, net of other factors. Each unit of increase in support of negotiations' ability to resolve inter-ethnic conflict cuts the probability of migration by more than half, holding other variables constant.

Although optimism about the end of the conflict is statistically significant, it fails to convince potential refugees to stay. The fact that it is positively associated with the intention to migrate, holding other variables constant, is puzzling and could be a focus of inquiry in the future, with more questions focusing on the safety of family members left behind. These respondents might also have a more optimistic approach to life in general making them more optimistic about overcoming difficulties in the diaspora or at home. Finally, the end of a conflict does not necessarily mean immediate opportunities to reach a desired standard of living.

Overall, pseudo $R$-square indicates an improved model fit. This model classifies $74 \%$ of the cases correctly.

\section{Social Capital}

The third model adds the following four social capital variables: positive feelings about community diversity, trust in Iraq's future, duty to keep the country united and negative feelings about displaced people in general. None of the social capital variables is significant, with the exception of negative feelings towards forcibly displaced people; respondents who feel insecure around displaced people are about six times more likely 
to remain in Iraq, holding other factors constant. Contrary to our expectations, there is no significant evidence of patriotism in the decision to stay; "Iraqis have a duty to keep Iraq united" is not a significant predictor. There is very little difference between this and previous models in terms of the strength and significance of socioeconomic variables.

Pseudo $R$-square indicates a stronger model fit. This model classifies $74 \%$ of the cases correctly.

\section{Odds of Migration Inside Iraq (Potential Internally Displaced)}

\section{Socioeconomic Factors}

We apply the same three models to respondents indicating an intention to move within Iraq within the next three years (Table 3). In the first model, civil status and type of employment are not statistically significant, similar to the model for refugees. Unlike the refugee model, however, age is not statistically significant, and Sunni identification and income level are. Respondents whose income is below national average are six times more likely to remain in their current location, net of other factors; it is possible that "poorer" respondents may feel their opportunities are limited elsewhere within Iraq, hence their decision to remain in their hometown. As expected, Sunnis are 2.1 times more likely to migrate than Shi'ite and other Muslim or non-Muslim groups, holding other factors constant (Table 4).

While the percentage of well-educated respondents who plan to move within Iraq is lower than the percentage of potential refugees ( $57 \mathrm{vs} 63 \%$ ), education is still statistically significant in the first model; well-educated respondents are 1.5 times more likely to migrate, net of other factors.

Pseudo $R$-square indicates a much weaker model fit. Overall, this model does not offer extremely accurate predictions, as it classifies only $66 \%$ of the cases correctly.

\section{Political Violence and Forced Displacement}

In the second model of potential internally displaced people, socioeconomic predictors vary in significance and strength compared to the previous model; age and civil status are statistically significant, but income level and education are not. As the average age of the respondents is below 40, we pay more attention to the remaining variables. Each unit of increase in married respondents decreases the probability of migration by more than half, holding other variables constant. Sunnis are two times more likely to migrate within Iraq, net of other factors.

In contrast, the political violence variables are not all that different in terms of significance and strength; respondents who hold the Shi'ite militia responsible for post2003 violence in Iraq are 1.6 times more likely to migrate than those who do not, holding other factors constant. Each unit of increase in support for negotiations as able to resolve inter-ethnic conflict cuts the probability of migration by more than half, net of other factors. Belief that the armed conflicts are likely to end in Iraq within three years is a strong predictor as well; these particular respondents are 3.3 times more likely to migrate within Iraq, provided all remaining variables stay the same.

Pseudo $R$-square indicates an improved but still weak model fit. This model classifies $70 \%$ of the cases correctly. 
Table 3 Odds ratios for logistic regression of forced migration within Iraq

\begin{tabular}{|c|c|c|c|}
\hline Independent variables & Model 1 & Model 2 & Model 3 \\
\hline \multicolumn{4}{|l|}{ Socioeconomic } \\
\hline \multirow[t]{2}{*}{ Age } & 0.984 & $0.976^{*}$ & $0.975^{*}$ \\
\hline & $(0.012)$ & $(0.013)$ & $(0.013)$ \\
\hline \multirow[t]{2}{*}{ Married } & 0.885 & $0.666^{*}$ & 0.681 \\
\hline & $(0.200)$ & $(0.164)$ & $(0.171)$ \\
\hline \multirow[t]{2}{*}{ Employed } & 0.965 & 0.937 & 0.974 \\
\hline & $(0.250)$ & $(0.255)$ & $(0.272)$ \\
\hline \multirow[t]{2}{*}{ Income } & $0.638 * *$ & 0.733 & 0.713 \\
\hline & $(0.132)$ & $(0.159)$ & $(0.158)$ \\
\hline \multirow[t]{2}{*}{ Sunni } & $2.135^{* *}$ & $2.021 * *$ & $1.900^{*}$ \\
\hline & $(0.654)$ & $(0.653)$ & $(0.625)$ \\
\hline \multirow[t]{2}{*}{ Education } & $1.465^{*}$ & 1.401 & 1.285 \\
\hline & $(0.321)$ & $(0.321)$ & $(0.301)$ \\
\hline \multicolumn{4}{|l|}{ Political violence } \\
\hline \multirow[t]{2}{*}{ Conflict end } & & $3.253 * * *$ & 3.137 *** \\
\hline & & $(0.713)$ & $(0.706)$ \\
\hline \multirow[t]{2}{*}{ Negotiation } & & $0.647^{*}$ & $0.652^{*}$ \\
\hline & & $(0.149)$ & $(0.159)$ \\
\hline \multirow[t]{2}{*}{ Shi'ite militia } & & $1.608^{* *}$ & $1.712 * *$ \\
\hline & & $(0.358)$ & $(0.395)$ \\
\hline \multicolumn{4}{|l|}{ Social capital } \\
\hline \multirow[t]{2}{*}{ Community } & & & 0.899 \\
\hline & & & $(0.0701)$ \\
\hline \multirow[t]{2}{*}{ Trust in Iraq's future } & & & $1.878^{* * * *}$ \\
\hline & & & $(0.450)$ \\
\hline \multirow[t]{2}{*}{ United } & & & 0.845 \\
\hline & & & $(0.260)$ \\
\hline \multirow[t]{2}{*}{ Displacement } & & & $0.629 * *$ \\
\hline & & & $(0.144)$ \\
\hline \multirow[t]{2}{*}{ Constant } & 1.039 & 0.732 & 1.283 \\
\hline & $(0.447)$ & $(0.356)$ & $(0.879)$ \\
\hline McFadden's $R^{2}$ & $3.3 \%$ & $10.1 \%$ & $12.2 \%$ \\
\hline Number of respondents & 441 & 441 & 441 \\
\hline
\end{tabular}

$* * * p<0.01$

$* * p<0.05$

$* p<0.1$

Numbers in parentheses are standard errors 
Table 4 Comparing migration intention of potential refugees and IDPs

\begin{tabular}{|c|c|c|c|}
\hline & & \multicolumn{2}{|l|}{ Overall } \\
\hline & & Intend to migrate & Do not intend to migrate \\
\hline \multirow[t]{4}{*}{ Religious composition } & Shia & $61 \%$ & $71 \%$ \\
\hline & Sunni & $15 \%$ & $9 \%$ \\
\hline & Muslim (other) & $18 \%$ & $17 \%$ \\
\hline & Christian & $6 \%$ & $4 \%$ \\
\hline Median age & & 30 & 32 \\
\hline \multirow[t]{2}{*}{ Gender composition } & Male & $89 \%$ & $96 \%$ \\
\hline & Female & $11 \%$ & $4 \%$ \\
\hline Permanent job & & $23 \%$ & $28 \%$ \\
\hline Well educated & & $61 \%$ & $42 \%$ \\
\hline Married & & $51 \%$ & $54 \%$ \\
\hline \multirow[t]{3}{*}{ Have children } & & $41 \%$ & $47 \%$ \\
\hline & & (Potential) refugees & \\
\hline & & Intend to migrate & Do not intend to migrate \\
\hline \multirow[t]{4}{*}{ Religious composition } & Shia & $26 \%$ & $69 \%$ \\
\hline & Sunni & $18 \%$ & $10 \%$ \\
\hline & Muslim (other) & $7 \%$ & $17 \%$ \\
\hline & Christian & $32 \%$ & $5 \%$ \\
\hline Median age & & 29 & 34 \\
\hline \multirow[t]{2}{*}{ Gender composition } & Male & $90 \%$ & $94 \%$ \\
\hline & Female & $10 \%$ & $6 \%$ \\
\hline Permanent job & & $23 \%$ & $28 \%$ \\
\hline Well educated & & $63 \%$ & $43 \%$ \\
\hline Married & & $46 \%$ & $50 \%$ \\
\hline \multirow[t]{3}{*}{ Have children } & & $35 \%$ & $57 \%$ \\
\hline & & (Potential) IDPs & \\
\hline & & Intend to migrate & Do not intend to migrate \\
\hline \multirow[t]{4}{*}{ Religious composition } & Shia & $60 \%$ & $70 \%$ \\
\hline & Sunni & $17 \%$ & $9 \%$ \\
\hline & Muslim (other) & $17 \%$ & $17 \%$ \\
\hline & Christian & $6 \%$ & $5 \%$ \\
\hline Median age & & 31 & 32 \\
\hline \multirow[t]{2}{*}{ Gender composition } & Male & $91 \%$ & $93 \%$ \\
\hline & Female & $9 \%$ & $7 \%$ \\
\hline Permanent job & & $27 \%$ & $25 \%$ \\
\hline Well educated & & $57 \%$ & $47 \%$ \\
\hline Married & & $49 \%$ & $54 \%$ \\
\hline Have children & & $38 \%$ & $48 \%$ \\
\hline
\end{tabular}




\section{Social Capital}

In the third model of potential internal displacement, the significance and strength of socioeconomic and political violence predictors do not considerably change from the second model, except for civil status; being married is no longer statistically significant. However, this model shows some interesting differences from the third model for potential refugees, as trust in Iraq's future and negative feelings towards displaced people are both statistically significant. Once again, the "duty to keep Iraq united" is not significant. This helps us differentiate optimism from patriotism; based on this finding, we conclude that patriotism does not play a key role in the decision-making process of intention to move within Iraq, but an optimistic outlook about the country's future does. Contrary to our expectations, increased trust in Iraq's future increases the odds of internal migration approximately 1.9 times, suggesting optimism about Iraq's future might also lead to optimism about the prospects of relocation.

Pseudo $R$-square indicates a slightly stronger model fit. This model classifies $72 \%$ of the cases correctly.

\section{Discussion of Findings}

While not all demographic variables play a significant role in the migration decision, the findings in the second and third model for potential refugees support the hypothesis that being permanently employed and having below national average income are significant predictors of the decision to migrate outside Iraq. Permanently employed people are less likely to leave than people with other types of employment, but those whose income falls below the national average are more likely to move. These results indicate that potential refugees value economic security, stability and material gains. The most outstanding result of socioeconomic variables for future refugees is for education levels; respondents who intend to leave the country are well-educated; $46 \%$ have a university degree or above and $63 \%$ have a secondary education and above. Contrary to our expectations, about half of the respondents who think the armed conflict will stop within the next three years also intend to leave Iraq within the same timeframe. This profile suggests that these respondents might have a more optimistic approach to life in general, including potential opportunities abroad. It is equally possible that they are not just looking for conflict to end; they may also be looking for a place where their families can enjoy the quality of life they had before the conflict, highlighting two points about forced migration. First, relative needs can be just as important as absolute needs in the decision to flee even in life threatening circumstances. Second, the decision to flee is not impulsive; it is calculated and "educated".

Unexpectedly, the relationship between being well-educated and the intention to migrate is not relevant for potential internally displaced people; in this case, education is not a statistically significant predictor, except in the first model. Sunni identity is significant for respondents who intend to migrate within Iraq but not for those who intend to move outside the country. However, predictors of political violence are just as significant for potential IDPs as they are for potential refugees, albeit with minor differences. Among respondents who are optimistic about the conflict's end in the third model, potential IDPs are 3.1 times more likely to move and potential 
refugees are 2.8 more likely. In addition, respondents who blame the Shi'ite militia are 1.7 times more likely to move within Iraq and 2.1 times more likely to migrate outside Iraq, net of other factors.

Interestingly, only about half of all respondents with experience of violence say that they intend to leave Baghdad within three years, and this piqued our interest. More than half $(52 \%)$ of those in favour of staying think all Iraqis can live together. Although they admit "trust is lost", they still think "inter-ethnic conflicts in Iraq could be resolved through negotiations", and this decreases the odds of migration, both internally and externally. We attempted to differentiate optimism from patriotism by including socioeconomic, political violence and social capital variables in the final model. We did not find clear support for the patriotism argument, as "duty to keep Iraq united" is not statistically significant in any of the models. We therefore revisited education, one of the strongest variables, to gain a better understanding of the profile of respondents who intend to stay in their place of origin. Among those in favour of leaving, $42 \%$ have secondary school and above education; only $25 \%$ have university or higher-level education. This is not to suggest the less-educated people are more patriotic; rather, lower levels of education may indicate a weaker understanding of events and encourage optimism. For example, although $52 \%$ of the respondents exposed to violence think Iraqis can still live together, fewer than half of the $52 \%$ agree "inter-ethnic conflicts in Iraq could be resolved through negotiations". Given these contradictory responses, we cannot include patriotism as a main driver of people's decisions to remain in their homes despite their exposure to violence.

Admittedly, the study has limitations. A deeper interrogation of the decision-making process of migration during violent ethnic conflicts is limited by the unavailability of data. A main shortcoming is the lack of detailed violence data because of sampling limitations; respondents with a history of witnessing physical injury, imprisonment, torture or other types of violence also report experiencing direct violence; so, we were not able to test for potential differences between direct and indirect violence. Nevertheless, these variables can still prove useful; although political violence is known to be a major push factor, we cannot assume every type and level of political violence will produce refugees and internally displaced people. Based on the theory that "witnesses as well as victims are subject to the dialectic of trauma" (Herman 1998: 2) and violence "can create a 'transgenerational' trauma" (Weingarten 2004), it would be ideal to test for the effect of witnessing violence versus experiencing violence on the individual decision to flee. Another limitation stemming from the unavailability of the data is the lack of a follow-up survey on the reasons for the intention to migrate within or outside Iraq. Finally, given the relative weakness of the models for potential internally displaced people, there are more unanswered questions on their decision-making processes than those of refugees.

\section{Conclusion}

Displacement is not new in Iraq; it is not simply the consequence of the 2003 conflict or the subsequent sectarian violence. As Ferris (2008: x) argues, displacement is not an accidental outcome of conflict. Understanding the historical context leads to additional 
insights into the effects of social and socioeconomic factors in the decision of individuals to move or stay in their ancestral home.

The survey we used gave us an opportunity to analyse Iraqis who intend to remain in their origin and potential migrants, thus adding to the literature. Importantly, people who intend to stay in their area of origin and are not migrating to other countries or to another area of Iraq are not "invisible" in this study; their presence prevents an overemphasis on the push factors that produce refugees.

The Iraqi survey sheds light on one of the darkest periods in the country's history by providing information on the circumstances that push/pull people to leave/stay when faced with political violence and ethnic conflict. While the data confirm previous findings in similar cases about the relationship between political violence and forced migration (García 2006; Engel and Ibáñez 2007; Czaika and Kis-Katos 2009; Holmes and De Piñeres 2011; Zetter et al. 2013; Balcells and Steele 2016; Bohnet et al. 2018), our study brings new information to public debates, with particular relevance for antiimmigrant platforms and the refugee crisis. For one thing, we show the ambiguous effect of economic status on the process of shaping migration intentions; for another, our basic yet useful socioeconomic profile of the public in the post-Saddam period indicates that potential refugees are generally well-educated (unlike common assumptions) and represent families with children.

Future research can benefit from follow-up surveys probing the decision-making process, particularly in terms of the motivating factors in the decision to stay or to move from or within a country experiencing armed conflict, and asking how much, if at all, patriotic or nationalist sentiments play a role in pursuit of the dream of a peaceful Iraq. Better understanding Iraq's forced migration problem could help to produce sustainable strategies addressing protracted displacement in Iraq and elsewhere (Zetter and Long 2012). In a larger context, as one of the main reasons for migration policy failure is the inability to identify and analyse factors related to the social dynamics of the migratory process (Castles 2004), a widespread use of surveys like ours could produce policy relevant results, helping to deal with forced migration cases worldwide.

Acknowledgements We would like to thank the British Academy for its generous support towards the survey in Iraq (Mid-Career Fellowship to the third author entitled The Way Home: Peaceful Return of Victims of Forced Displacement MD140005). We are also very grateful to Dr Djordje Stefanovic for contributing to the design of the questionnaire for this survey.

Open Access This article is distributed under the terms of the Creative Commons Attribution 4.0 International License (http://creativecommons.org/licenses/by/4.0/), which permits unrestricted use, distribution, and reproduction in any medium, provided you give appropriate credit to the original author(s) and the source, provide a link to the Creative Commons license, and indicate if changes were made.

\section{References}

Adhikari, P. (2012). Conflict-induced displacement, understanding the causes of flight. American Journal of Political Science, 57, 82-89.

Balcells, L., \& Steele, A. (2016). Warfare, political identities and displacement in Spain and Colombia. Political Geography, 51, 15-29. 
Baser, B. (2014). The awakening of a latent diaspora: the political mobilization of first and second generation Turkish migrants in Sweden. Ethnopolitics, 13, 355-376.

Batatu, H. (2003). The Old Social Classes and the Revolutionary Movements of Iraq: From the Ottoman to the Republic (Third ed., Translated By Afif al-Razaz). Kuwait: Dar Al-Qabas.

Bertoli, S., \& Ruyssen, I. (2018). Networks and migrants' intended destination. Journal of Economic Geography.

Betts, A. (2016). Refugee Economies: Forced Displacement and Development. Oxford: Oxford University Press.

Bohnet, H., Cottier, F., \& Hug, S. (2018). Conflict-induced IDPs and the spread of conflict. Journal of Conflict Resolution, 62, 691-716.

Bohra-Mishra, P., \& Massey, D. S. (2011). Individual decisions to migrate during civil conflict. Demography, $48,401-424$.

Borjas, G. J. (1990). Friends or Strangers: The Impact of Immigrants on the U.S. Economy. New York: Basic Books.

Calhoun, C. (2010). Beck, Asia and second modernity. British Journal of Sociology, 61(3), 597-619.

Carling, J., \& Schewel, K. (2018). Revisiting aspiration and ability in international migration. Journal of Ethnic and Migration Studies, 44(6), 945-963.

Castles, S. (2004). Why migration policies fail. Ethnic and Racial Studies, 27(2), 205-227.

Cenciarelli, O., Mancinelli, S., Ludovici, G. M., \& Palombi, L. (2017). Migration and Terrorism: A New Approach to Consider the Threat. In M. Martellini \& A. Malizia (Eds.), Cyber and Chemical, Biological, Radiological, Nuclear, Explosives Challenges (pp. 277-287). Cham: Springer International Publishing.

Chatelard, G. (2010) 'The Politics of Population Movements in Contemporary Iraq: A Research Agenda'. https://halshs.archives-ouvertes.fr/halshs-00511957/document. Accessed 12 December 2017.

Cheung, S. Y., Phillimore, J. (2013) 'Social Networks, Social Capital and Refugee Integration'. Nuffield Foundation Report.

Collier, P. (2013). Exodus: How Migration Is Changing Our World. Oxford; New York: Oxford University Press.

Cooke, T. J. (2008). Migration in a family way. Population, Space and Place, 14, 255-265.

Cortes, K. E. (2004). Are refugees different from economic immigrants? Some empirical evidence on the heterogeneity of immigrant groups in the United States. The Review of Economics and Statistics, 86, 465480.

Czaika, M., \& Kis-Katos, K. (2009). Civil conflict and displacement: village-level determinants of forced migration. Aceh. J. Peace Res., 46, 399-418.

Damelang, A., \& Haas, A. (2012). The benefits of migration: cultural diversity and labour market success. European Societies, 14(3), 362-392.

Davenport, C., Moore, W. H., \& Poe, S. C. (2003). Sometimes you just have to leave: domestic threats and forced migration, 1964-1989. International Interactions, 29, 27-55.

Dawisha, A. (2013). Iraq: A Political History. Princeton and Oxford: Princeton University Press.

De Jong, G. F. (2000). Expectations, gender, and norms in migration decision-making. Population Studies, 54, 307-319.

De Jong, G. F., Root, B. D., Gardner, R. W., Fawcett, J. T., \& Abad, R. G. (1985). Migration intentions and behavior: decision making in a rural Philippine Province. Population and Environment, 8(1), 41-62.

Dryden-Peterson, S. (2011) Refugee Education: A Global Review. UN High Commissioner for Refugees (UNHCR).

DTM (2018) Round 107. IOM Iraq. http://iraqdtm.iom.int. Accessed 20 January 2019.

Duda-Mikulin, E. A. (2018). Should I stay or should I go now? Exploring Polish women's returns "home". International Migration, 56, 140-153.

Edwards, S. (2009). The Chaos of Forced Migration: A Means of Modeling Complexity for Humanitarian Ends. Saarbrucken, Germany: VDM Verlag.

Engel, S., \& Ibáñez, A. M. (2007). Displacement due to violence in Colombia: a household-level analysis. Economic Development and Cultural Change, 55, 335-365.

Etling, A., Backeberg, L., \& Tholen, J. (2018). The political dimension of young people's migration intentions: evidence from the Arab Mediterranean region. Journal of Ethnic and Migration Studies, 1-17.

Fawcett, J., Cohen, R. (2002) 'The Internally Displaced People of Iraq'. https://www.brookings. edu/research/the-internally-displaced-people-of-iraq-2/. Accessed 2 July 2017.

Fawcett, J., Tanner, V. (2002) 'The Internally Displaced People of Iraq'. Brookings Institution. https://www. brookings.edu/wp-content/uploads/2016/06/iraqreport.pdf. Accessed 2 July 2017. 
Ferris, E. G. (2008) 'The Looming Crisis: Displacement and Security in Iraq'. Foreign policy at Brookings, policy paper no. 5. https://www.brookings.edu/wp-content/uploads/2016/06/08_iraq ferris.pdf. Accessed 13 August 2017.

García, M. C. (2006). Seeking Refuge: Central American Migration to Mexico, the United States and Canada. Berkeley: University of California Press.

Goodman, S., Sirriyeh, A., \& McMahon, S. (2017). The evolving (re)categorisations of refugees throughout the "refugee/migrant crisis". Journal of Community and Applied Social Psychology, 27, 105-114.

Guveli, A., Ganzeboom, H. B. G., Baykara-Krumme, H., Platt, L., Eroğlu, Ș., Spierings, N., Bayrakdar, S., Nauck, B., \& Sozeri, E. K. (2017). 2,000 families: identifying the research potential of an origins-ofmigration study. Ethnic and Racial Studies, 40, 2558-2576.

Hartog, J., \& Zorlu, A. (2009). How important is homeland education for refugees' economic position in the Netherlands? Journal of Population Economics, 22(1), 219-246.

Haug, S. (2008). Migration networks and migration decision making. Journal of Ethnic and Migration Studies, 34(4), 590.

Herman, J. L. (1998). Trauma and Recovery. London: Pandora.

Holmes, J. S., \& De Piñeres, S. A. G. (2011). Conflict-induced displacement and violence in Colombia. Stud. Confl. Terror., 34, 572-586.

Ibanez, A. M., \& Velez, C. E. (2008). Civil conflict and forced migration: the micro determinants and welfare losses of displacement in Columbia. World Development, 36(4), 659-676.

Internal Displacement Monitoring Centre (IDMC) (2018) Country Information (Iraq). http://www.internaldisplacement.org/countries/iraq. Accessed 21 September 2018.

International Labour Organisation (2013) 'Assessment of the Impact of Syrian Refugees in Lebanon and Their Employment Profile’, p. 19. https://data.unhcr.org/syrianrefugees. Accessed 21 January 2018.

IOM (2011) Glossary on Migration, International Migration Law (25). https://www.iom.int/key-migrationterms. Accessed 11 January 2019.

Jacobsen, K. (2005). The Economic Life of Refugees. Bloomfield, CT: Kumarian Press.

Khawaja, M., Assaf, S., \& Yamout, R. (2010). Predictors of displacement behaviour during the 2006 Lebanon war. Global Public Health, 6(5), 488-504.

Lee, E. (1966). A theory of migration. Demography, 3, 47-57.

Liebig, T., \& Sousa-Poza, A. (2004). Migration, self-selection and income inequality: an international analysis. Kyklos, 57, 125-146.

Loescher, G., \& Milner, J. (2005). Protracted Refugee Situations: Domestic and International Security Implications'. Adelphi paper. Abingdon; New York: Routledge for the International Institute of Strategic Studies.

Loizos, P. (2000). Are Refugees Social Capitalists? Social Capital: Critical Perspectives. New York: Oxford University Press.

Marr, P. (2004). The Modern History of Iraq. Colorado: Westview Press.

Martin, S., Weerasinghe, S., \& Taylor, A. (2014). What is crisis migration? Forced Migration Review, 45, 5-9.

Mcauliffe, M., \& Jayasuriya, D. (2016). Do asylum seekers and refugees choose destination countries? Evidence from large-scale surveys in Australia, Afghanistan, Bangladesh, Pakistan and Sri Lanka. International Migration, 54, 44-59.

Melander, E., \& Öberg, M. (2006). Time to go? Duration dependence in forced migration. Empirical and Theoretical Research in International Relations, 32(2), 129-152.

Melander, E., \& Öberg, M. (2007). The threat of violence and forced migration: geographical scope trumps intensity of fighting. Forced Migration and Civil War, 9(2), 156-173.

Mincer, J. (1978). Family migration decisions. Journal of Political Economy, 86(5), 749-773.

Moore, W. H., \& Shellman, S. M. (2004). Fear of Persecution. Journal of Conflict Resolution, 48(5), 723-745.

Moore, W. H., \& Shellman, S. M. (2006). Refugee or internally displaced person? To where should one flee? Comparative Political Studies, 39(5), 599-622.

Moore, W. H., \& Shellman, S. M. (2007). Whither will they go? A global study of refugees' destinations, 1965-1995. International Studies Quarterly, 51(4), 811-834.

Morrice, L. (2007). Lifelong learning and the social integration of refugees in the UK: the significance of social capital. International Journal of Lifelong Education, 26(2), 155-172.

Mueller, C. F. (1982). The Economics of Labour Migration: A Behavioural Analysis, Studies in Urban Economics. New York: Academic Press. 
Neumayer, E. (2005). Bogus refugees? The determinants of asylum migration to Western Europe. International Studies Quarterly, 49(3), 389-409.

Randell, H. (2016). Structure and agency in development-induced forced migration: the case of Brazil's Belo Monte dam. Population and Environment, 37(3), 265-287.

Ravenstein, E. (1885). The laws of migration. Journal of The Statistical Society, 48, 167-235.

Ravenstein, E. (1889). The laws of migration: second paper. Journal of the Royal Statistical Society, 52, 241-305.

Robinson, V., Segrott, J. (2002) 'Understanding the Decision-Making of Asylum Seekers'. Great Britain, Home Office, Research, D. and S.D. Home Office, London.

Ruiz, I., \& Vargas-Silva, C. (2013). The economics of forced migration. The Journal of Development Studies, 49(6), 772-784.

Schmeidl, S. (1997). Exploring the causes of forced migration: a pooled time-series analysis, 1971-1990. Social Science Quarterly, 78, 284-308.

Sirkeci, I. (2005). War in Iraq: environment of insecurity and international migration. International Migration, 43(4), 197-214.

Smith, Y. J. (2013). We all bantu—we have each other: preservation of social capital strengths during forced migration. Journal of Occupational Science, 20(2), 173-184.

Spreen, C. A., \& Vally, S. (2012). Monitoring the right to education for refugees, migrants and asylum seekers. Southern African Review of Education, 18(2), 71-89.

Stansfield, G. (2007). Iraq: People, History, Politics. Cambridge: Polity Press.

Stats NZ (2017) 'Outcomes Versus Intentions: Measuring Migration Based on Travel Histories'. https://www. stats.govt.nz. Accessed 14 September 2018.

Steele, A. (2009). Seeking safety: avoiding displacement and choosing destinations in civil wars. Journal of Peace Research, 46(3), 419-429.

Stefanovic, D., \& Loizides, N. (2011). The way home: peaceful return of victims of ethnic cleansing. Human Rights Quarterly, 33(2), 408-430.

Stefanovic, D., Loizides, N., \& Parsons, S. (2014). Home is where the heart is? Forced migration and voluntary return in Turkey's Kurdish regions. Journal of Refugee Studies, 28(2), 276-296.

Tjaden, J., Auer, D., \& Laczko, F. (2019). Linking migration intentions with flows: evidence and potential use. International Migration, 57, 36-57.

Tripp, C. (2007). A History of Iraq. Cambridge: Cambridge University Press.

Tsourapas, G. (forthcoming). The Syrian refugee crisis and foreign policy decision-making in Jordan, Lebanon, and Turkey. Journal of Global Security Studies.

UNHCR. (2010). Global Protection Cluster (GPC), 'Handbook for the Protection of Internally Displaced Persons'. June 2010. http://www.unhcr.org/4c2355229.pdf. Accessed 23 August 2017.

UNHCR. (2012). 'Global Trends: Forced Displacement in 2011', available at: http://www. unhcr/org/uk/statistics/country/4fd6f87f9/unhcr-global-trends-2011.html. Accessed 23 September 2018.

UNHCR. (2016). 'Global Trends: Forced Displacement in 2015', available at: http://www.unher. org/uk/statistics/unhcrstats/576408cd7/unhcr-global-trends-2015.html. Accessed 4 July 2017.

UNHCR. (2017). 'Global Trends: Forced Displacement in 2017', available at: https://www.unhcr.org/5b27 be547.pdf. Accessed 23 Sept 2018.

UNHCR. (n.d.). The 1951 Convention Relating to the Status of Refugees and Its 1967 Protocol, September 2011, available at: https://www.unhcr.org. Accessed 16 January 2019.

Van Dalen, H. and Henkens, K. (2008) 'Emigration Intentions: Mere Words or True Plans? Explaining International Migration Intentions and Behaviour'. No 2008-60, Discussion Paper. Tilburg University, Centre for Economic Research.

Van Dalen, H. P., \& Henkens, K. (2013). Explaining emigration intentions and behaviour in the Netherlands. Population Studies, 67, 225-241.

Van Hear, N. (2006). In D. Moss (Ed.), I Went as Far as My Money Would Take Me: Conflict, Forced Migration and Class in Gender, Space and Time: Women and Higher Education. Lanham: Lexington Books.

Vezzoli, S., Bonfiglio, A., De Haas, H. (2017) Global Migration Futures: Exploring the Future of International Migration with a Scenario Methodology. International Migration Institute (IMI).

Wardi, A. (1976). Lamahat Ijtimaya min Tarikh al-Iraq al-Hadith: from 1920-1924. Baghdad: Al-Maarf.

Weiner, M. (1996). Bad neighbours, bad neighbourhoods: an inquiry into the causes of refugee flows. International Security, 21(1), 5-42. 
Weingarten, K. (2004). Witnessing the effects of political violence in families: mechanisms of intergenerational transmission and clinical interventions. Journal of Marital and Family Therapy, 30, 45-59.

Weinstein, E. R. (2002). Migration for the benefit of all: towards a new paradigm for economic immigration. International Labour Review, 141(3), 225-252.

Wood, E. J. (2008). The social processes of civil war: the wartime transformation of social networks. Annual Review of Political Science, 11, 539-561.

World Bank (2015) Data: Iraq in 2015. https://data.worldbank.org/country/iraq. Accessed 13 June 2017.

Zetter, R. (2007). More labels, fewer refugees: remaking the refugee label in an era of globalization. Journal of Refugee Studies, 20, 172-192.

Zetter, R. (2012a). Unlocking protracted displacement. Forced Migration Review, 40, 34-37.

Zetter, R. (2012b). Are refugees an economic burden or benefit? Forced Migration Review, 41, 50-52.

Zetter, R., \& Long, K. (2011). Unlocking Protracted Displacement. Forced Migration Review, 40, $34-37$.

Zetter, R., Purdekova, A., Londoño, A.M.I. (2013) 'Violence, conflict, and mobility: a micro-level analysis'. In: Justino, P., Brück, T., Verwimp, P. (Eds.), A Micro-Level Perspective on the Dynamics of Conflict, Violence and Development. Oxford University Press, 206-227.

Zimmermann, S. E. (2011). Reconsidering the Problem of 'Bogus' Refugees with 'Socio-economic Motivations' for Seeking Asylum. Mobilities, 6(3), 335-352.

Zolberg, A. R., Suhrke, A., \& Aguayo, S. (1992). Escape from Violence: Conflict and the Refugee Crisis in the Developing World. First issued as an Oxford Univ. Press paperback. New York: Oxford Univ. Press.

Publisher's Note Springer Nature remains neutral with regard to jurisdictional claims in published maps and institutional affiliations. 